MAGDALENA LESIAK

Uniwersytet Lódzki, Polska - University of Lodz, Poland

\title{
Istota analizy wskaźnikowej - ujęcie edukacyjne
}

\section{The essence of index analysis - educational approach}

Streszczenie: Celem artykułu jest charakterystyka narzędzi analizy wskaźnikowej na podstawie analizy literatury przedmiotu. Zastosowana metoda ilościowa ma istotne znaczenie dla określenia kondycji finansowej przedsiębiorstwa ze względu na możliwość przeprowadzenia syntetycznej oceny efektywności finansowej badanego podmiotu. Na szerokie możliwości aplikacyjne analizy wskaźnikowej wskazuje fakt, iż obejmuje ona obszary płynności, rentowności, zadłużenia oraz sprawności działania, czyli tzw. obrotowości, co bezpośrednio przyczynia się do kompleksowej oceny standingu finansowego przedsiębiorstwa. Potwierdza to również dokonana wiwisekcja literatury, której wyniki jednoznacznie unaoczniły, że analiza wskaźnikowa umożliwia określenie zjawisk świadczących zarówno o sile, jak i o słabościach badanej jednostki gospodarczej. Ponadto nie tylko stwarza możliwość określenia kondycji finansowej, ale także stanowi podstawę do podejmowania decyzji o charakterze finansowo-inwestycyjnym. Tym samym znajduje szerokie i praktyczne zastosowanie na różnych szczeblach zarządzania jednostką.

\begin{abstract}
The purpose of the article is to characterise the tools of index analysis based on the literature of the subject. This quantitative method is important for determining the financial condition of an enterprise due to the possibility of carrying out a synthetic assessment of the financial efficiency of the audited entity. The wide application possibilities of index analysis are indicated by the fact that it covers the areas of liquidity, profitability, debt and efficiency, i.e. the so-called turnover, which directly contributes to a comprehensive assessment of the financial standing of the company. This is also confirmed by the vivisection of the literature, the results of which have clearly shown that index analysis makes it possible to identify phenomena indicating both the strengths and weaknesses of the economic unit under investigation. Moreover, it provides an opportunity to not only determine the financial condition, but also provides the basis for financial and investment decisions. It thus finds wide and practical application at different levels of management of the unit.
\end{abstract}

Słowa kluczowe: analiza wskaźnikowa; płynność finansowa; rentowność; sprawność działania przedsiębiorstwa; zadłużenie

Keywords: debt; financial liquidity; operational efficiency of enterprises; profitability; ratio analysis 
Otrzymano: 17 października 2020

Received: 17 October 2020

Zaakceptowano: 2 marca 2021

Accepted: 2 March 2021

\section{Sugerowana cytacja/Suggested citation:}

Lesiak, M. (2021). Istota analizy wskaźnikowej - ujęcie edukacyjne. Przedsiębiorczość - Edukacja [Entrepreneurship - Education], 17(1), 220-233. https://doi.org/10.24917/20833296.171.17

\section{Wstęp}

Analiza wskaźnikowa według L. Szyszko i J. Szczepańskiego (2003) stanowi rozwinięcie wstępnej analizy bilansu, rachunku zysków i strat oraz sprawozdania z przepływów środków pieniężnych. Analiza ta opiera się na ustaleniu relacji pomiędzy różnymi pozycjami bilansu i rachunku zysków i strat oraz porównaniu ich z poziomami przyjętymi powszechnie za pożądane lub graniczne albo $\mathrm{z}$ ich poziomem $\mathrm{w}$ innych firmach danej branży. M. Jerzemowska (2004) uważa, że celem analizy wskaźnikowej jest pogłębienie i uszczegółowienie wyników badań uzyskanych dzięki przeprowadzeniu wstępnej analizy sprawozdań finansowych. Pozwala ona w głównej mierze na:

- ocenę minionych i teraźniejszych wyników działalności przedsiębiorstwa oraz i antycypowanie przyszłych wyników,

- identyfikację tych obszarów, które są niewłaściwie zarządzane i potencjalnie niebezpieczne,

- ocenę kondycji finansowej przedsiębiorstwa.

Należy zwrócić uwagę na fakt, iż wskaźniki finansowe można sklasyfikować bardzo odmiennie. Przykładowo w publikacji A. Pieloch-Babiarz oraz A. Sajnóg (2016) można odnaleźć m.in. sposób pogrupowania wskaźników finansowych na:

- wskaźniki płynności finansowej,

- wskaźniki rentowności,

- wskaźniki sprawności działania,

- wskaźniki zadłużenia i zdolności przedsiębiorstwa do obsługi długu.

\section{Wskaźniki płynności finansowej}

Płynność finansową utożsamia się ze zdolnością przedsiębiorstwa do terminowego regulowania zobowiązań bieżących (Burzykowska, Duraj, 2009). Ma ona istotne znaczenie dla bieżącego funkcjonowania jednostki gospodarczej. Jej niski poziom często jest skutkiem błędnych decyzji kierownictwa bądź jest wywoływany czynnikami zewnętrznymi.

Warto podkreślić, że od pojęcia płynności finansowej należy odróżnić takie terminy, jak: zdolność płatnicza, płynność majątku i wypłacalność. W literaturze przedmiotu odnaleźć można rożne ujęcia powyższych pojęć. Jednak dla celów tej pracy najbardziej adekwatne wydają się ujęcia K. Prędkiewicza (2007), J.G. Siegela, J.K. Shima, S.W. Hartmana (1995) oraz M. Sierpińskiej i D. Wędzkiego (2010).

Prędkiewicz uznaje, że wypłacalność to trwała zdolność przedsiębiorstwa do generowania wpływów na pokrycie niezbędnych wydatków związanych z prowadzoną działalnością (Prędkiewicz, 2007: 233). 
Płynność majątku to możliwość i tempo zmiany poszczególnych składników majątku na pieniądz bądź inną, łatwiej wydatkowaną formę aktywów bez lub z nieznaczną uratą wartości (Siegel, Shim, Hartman, 1995).

Zdolność płatnicza jest zdolnością kredytową rozumianą jako zdolność do spłaty zaciągniętego kredytu łącznie $\mathrm{z}$ odsetkami w terminach określonych w umowie (Pieloch-Babiarz, Sajnóg, 2016).

Wskaźniki płynności finansowej przedstawić można w ujęciu:

- statycznym - na dany moment bilansowy; dane czerpane są z bilansu przedsiębiorstwa,

- dynamicznym - za dany okres; analiza oparta jest na danych z rachunku przepływów pieniężnych (Sierpińska, Wędzki, 2010).

W ujęciu statycznym płynności finansowej wskaźniki prezentuje się w trzech poziomach płynności, oznaczanych numerami I-III.

Wskaźnik płynności bieżącej (current ratio), który wylicza się na III poziomie płynności finansowej, obrazuje zdolność przedsiębiorstwa do spłacenia wszystkich jego zobowiązań bieżących przez upłynnienie posiadanych zasobów majątku obrotowego (Pieloch-Babiarz, Sajnóg, 2016). Optymalna wartość tego wskaźnika jest różna dla poszczególnych branż i przedsiębiorstw, które mogą mieć odmienny okres zwrotu należności czy spłaty zobowiązań. Normą wartości wskaźnika płynności jest przedział 1,2-2,0. Oznacza to, że wartość bieżących aktywów powinna być około dwukrotnie większa niż bieżące zobowiązania. Za minimum bezpieczeństwa finansowego przyjmuje się wskaźnik o wartości 1,2. Wartość wskaźnika mniejsza niż 1,2 i większa niż 2 świadczy o złej sytuacji w przedsiębiorstwie (ING Securities, 2020, 15 września).

Wylicza się go ze wzoru (Dębski, 2013: 78):

$$
\mathrm{CR}=\frac{\mathrm{CA}}{\mathrm{CL}}
$$

gdzie:

CA - aktywa obrotowe, bez należności z tytułu dostaw i usług o okresie płynności powyżej roku (aktywa bieżące),

CL - zobowiązania bieżące, bez zobowiązań z tytułu dostaw i usług o okresie wymagalności powyżej roku.

Na poziomie II płynności finansowej wylicza się wskaźnik płynności szybkiej (quick ratio), który pokazuje stopień pokrycia zobowiązań krótkoterminowych aktywami o dużym stopniu płynności (Bień, 2010: 106-107):

$$
\mathrm{QR}=\frac{\mathrm{CA}-\mathrm{I}-\mathrm{STDA}}{\mathrm{CL}}
$$

gdzie:

I - zapasy,

STDA - krótkoterminowe rozliczenia międzyokresowe, pozostałe oznaczenia jw.

Porównywanie wskaźnika płynności bieżącej ze wskaźnikiem płynności szybkiej informuje o stanie zapasów. Im większa różnica między wartością wskaźnika płynności bieżącej a wskaźnikiem płynności szybkiej, tym większe jest zamrożenie kapitału w zapasach 
(Pieloch-Babiarz, Sajnóg, 2016). Podkreślić należy, iż wskaźnik ten jest znacznie dokładniejszy niż wskaźnik bieżącej płynności. W praktyce za zadowalający przyjmuje się poziom wskaźnika płynności szybkiej z przedziału 1,0-1,3 (ING Securities, 2020, 15 września).

Natomiast na I poziomie wyznacza się wskaźnik wypłacalności gotówkowej nazywany także mnożnikiem gotówkowym (MR) (Buk, Duraj, 2007: 173):

$$
\mathrm{MR}=\frac{\mathrm{CASH}}{\mathrm{CL}}
$$

gdzie:

CASH - środki pieniężne i ich ekwiwalenty, pozostałe oznaczenia jw.

Obrazuje on możliwość spłaty zobowiązań bieżących najbardziej płynną częścią majątku obrotowego, czyli gotówką w kasie, pieniędzmi na rachunku bankowym i innymi środkami pieniężnymi (weksle płatne do trzech miesięcy od daty wystawienia) (Pieloch-Babiarz, Sajnóg, 2016).

Wskaźnik natychmiastowej wypłacalności ukazuje, czy przedsiębiorstwo może spłacić swoje zobowiązania w dniu, na który te płatności przypadają (Pieloch-Babiarz, Sajnóg, 2016). Wylicza się go z następującego wzoru (Jerzemowska, 2004: 139):

$$
\mathrm{IS}=\frac{\text { ACASH }}{\mathrm{ICL}}
$$

gdzie:

ACASH - dostępne środki pieniężne,

ICL - natychmiast wymagalne zobowiązania,

pozostałe oznaczenia jw.

Odnosząc się do płynności finansowej, nie można pominąć terminu kapitału obrotowego netto (KON albo NWC), nazywanego kapitałem pracującym (working capital). Dysponowanie tym kapitałem odnosi się do gospodarowania aktywami obrotowymi i zobowiązaniami bieżącymi, aby zagwarantować odpowiednie funkcjonowanie, rozwój i wzrost wartości przedsiębiorstwa (Krajewski, 2006: 116). Ujmowany jest w dwóch podejściach, mianowicie w ujęciu kapitałowym albo majątkowym. W podejściu kapitałowym kapitał obrotowy netto jest częścią kapitału stałego, która finansuje majątek obrotowy (Pieloch-Babiarz, Sajnóg, 2016).

Wyznacza się go wg następującej formuły (Sierpińska, Jachna, 2007: 51):

$$
\mathrm{NWC}=\mathrm{FC}-\mathrm{FA}
$$

gdzie:

FC - kapitał stały,

FA - aktywa trwałe.

W ujęciu majątkowym wartość kapitału obrotowego netto wyznacza się zgodnie z wzorem (Grabowska, 2012: 35-39): 


$$
\mathrm{NWC}=\mathrm{CA}-\mathrm{CL}
$$

Odnieść należy się również do cyklu konwersji gotówki, który informuje o tym, jak długi odcinek czasu upływa od chwili wypływu środków pieniężnych z przedsiębiorstwa powiązanego z uregulowaniem zobowiązań wobec dostawców za zakupione produkty, usługi bądź materiały do chwili, w której pobierane są należności od odbiorców z tytułu sprzedaży wyrobów (Sierpińska, Jachna, 2007). Zatem jest on różnicą między cyklem operacyjnym a cyklem zobowiązań krótkoterminowych. Wyznaczany jest według następującej formuły (Burzykowska, Duraj, 2009: 67):

$$
\mathrm{CCC}=\mathrm{OC}-\mathrm{STLC}
$$

gdzie:

CCC - cykl konwersji gotówki,

OC - cykl operacyjny,

STLC - cykl zobowiązań krótkoterminowych.

Natomiast cykl operacyjny to czas ukazujący liczbę dni, przez które zapasy są utrzymywane przez przedsiębiorstwo, zsumowany z czasem uzyskania należności krótkoterminowych. Tak więc cykl zapasów i cykl należności krótkoterminowych składają się na cykl operacyjny (Michalski, 2010: 19-28):

$$
\text { OC }=\text { IC }- \text { STRC }
$$

gdzie:

IC - cykl zapasów (w dniach),

STRC - cykl należności krótkoterminowych.

Odnosząc się do wskaźników płynności finansowej w ujęciu dynamicznym, trzeba zaznaczyć, że są one rozwinięciem i uzupełnieniem analizy płynności w ujęciu statycznym. Wyróżnia się trzy podstawowe grupy wskaźników:

- wskaźniki struktury przepływów pieniężnych,

- wskaźniki wystarczalności pieniężnej,

\begin{tabular}{|c|c|}
\hline Wskaźnik & Wzór \\
\hline \multirow{2}{*}{$\begin{array}{l}\text { Udział zysku netto } \\
\text { w operacyjnej nadwyżce } \\
\text { pieniężnej }\end{array}$} & Zysk netto \\
\hline & $\overline{\text { Przeplywy pieniężne netto z działalności operacyjnej }}$ \\
\hline \multirow{2}{*}{$\begin{array}{l}\text { Udział amortyzacji } \\
\text { w operacyjnej nadwyżce } \\
\text { pieniężnej }\end{array}$} & Amortyzacja \\
\hline & $\overline{\text { Przeplywy pieniężne netto z działalności operacyjnej }}$ \\
\hline \multirow{2}{*}{$\begin{array}{l}\text { Zależność od } \\
\text { zewnętrznych źródeł } \\
\text { finansowania }\end{array}$} & Wpływy z działalności finansowej \\
\hline & Przepływy pieniężne netto z działalności operacyjnej \\
\hline
\end{tabular}

- wskaźniki wydajności pieniężnej (Wiśniewski, Skoczylas, 1997).

Tabela 1. Wskaźniki struktury przepływów pieniężnych 


\begin{tabular}{|l|l|}
\hline $\begin{array}{l}\text { Pieniężnej } \\
\text { samowystarczalności } \\
\text { działalności finansowej }\end{array}$ & \begin{tabular}{l} 
Wpływy z działalności finansowej \\
\cline { 1 - 2 }
\end{tabular} \\
\hline
\end{tabular}

Źródło: Jerzemowska (2004: 144-152)

Tabela 2. Wskaźniki wystarczalności pieniężnej

\begin{tabular}{|l|c|l|}
\hline \multicolumn{1}{|c|}{ Wskaźnik } & \multicolumn{1}{|c|}{ Wzór } & \multicolumn{1}{c|}{ Opis } \\
\hline $\begin{array}{l}\text { Wskaźnik ogólnej } \\
\text { wystarczalności } \\
\text { pieniężnej }\end{array}$ & $\begin{array}{c}\text { Środki pieniężne netto z dz.operacyjej } \\
\text { Spłata zobowiq̨zań długoterminowych + } \\
\text { zakupy inwestycyjne }+ \\
\text { + wypłata dywidend }\end{array}$ & $\begin{array}{l}\text { Zdolność } \\
\text { przedsiębiorstwa do } \\
\text { regulowania swoich } \\
\text { zobowiązań wobec } \\
\text { wierzycieli. Powinien } \\
\text { wynosić 1 lub więcej }\end{array}$ \\
\hline $\begin{array}{l}\text { Wskaźnik } \\
\text { wystarczalności } \\
\text { pieniężnej } \\
\text { operacyjnej na zakup } \\
\text { środków trwałych }\end{array}$ & $\frac{\text { Środki pieniężne netto z dz.operacyjej }}{\text { Wydatki na środki trwałe }}$ & $\begin{array}{l}\text { Zdolność do } \\
\text { utrzymywania } \\
\text { środków trwałych } \\
\text { z wypracowanej } \\
\text { gotówki }\end{array}$ \\
\hline
\end{tabular}

Źródło: Cicirko (2010: 105-106)

Tabela 3. Wskaźniki wydajności pieniężnej

\begin{tabular}{|l|l|l|}
\hline \multicolumn{1}{|c|}{ Wskaźnik } & \multicolumn{1}{|c|}{ Wzór } & \multicolumn{1}{c|}{ Opis } \\
\hline $\begin{array}{l}\text { Wskaźnik pieniężnej } \\
\text { wydajności sprzedaży }\end{array}$ & $\begin{array}{l}\text { Środki pieniężne z dz.operacyjnej } \\
\text { Przychody ze sprzedaży }\end{array}$ & $\begin{array}{l}\text { Relację wygenerowanych } \\
\text { środków pieniężnych } \\
\text { z działalności operacyjnej } \\
\text { do wielkości sprzedaży }\end{array}$ \\
\hline $\begin{array}{l}\text { Wskaźnik pieniężnej } \\
\text { wydajności zysku }\end{array}$ & $\frac{\text { Środki pieniężne z dz.operacyjnej }}{\text { Zysk } \mathrm{z} \text { dz.gospodarczej }}$ & $\begin{array}{l}\text { Jaki procent zysku jest } \\
\text { realizowany w gotówce }\end{array}$ \\
\hline $\begin{array}{l}\text { Wskaźnik pieniężnej } \\
\text { wydajności majątku }\end{array}$ & $\frac{\text { Środki pieniężne z dz.operacyjnej }}{\text { Przeciętny stan aktywów }}$ & $\begin{array}{l}\text { Zdolność aktywów } \\
\text { jednostki do generowania } \\
\text { środków pieniężnych }\end{array}$ \\
\hline
\end{tabular}

Źródło: Cicirko (2010: 105-106)

Mierniki płynności finansowej zarówno w ujęciu statycznym, w którym odnoszą się do danych z bilansu oraz rachunku zysków i strat, jak i w ujęciu dynamicznym, w którym czerpią informacje $\mathrm{z}$ rachunku przepływów pieniężnych, umożliwiają zarządzanie poziomem płynności sprowadzającej się do utrzymywania odpowiedniej ilości środków pieniężnych w przedsiębiorstwie. Opóźnienia w spłacaniu zobowiązań skutkują utraceniem zaufania swoich partnerów biznesowych i utratą wiarygodności wobec instytucji finansowych, a w skrajnych przypadkach mogą doprowadzić przedsiębiorstwo do bankructwa. Natomiast zbyt wysoki poziom płynności naraża przedsiębiorstwo na ponoszenie nadmiernych kosztów przejawiających się w zamrożeniu kapitału obrotowego, a tym samym obniżeniu rentowności przedsiębiorstwa. 
Wskaźniki zadłużenia i zdolności przedsiębiorstwa do obsługi długu

Analiza zadłużenia ukazuje znaczenie kapitałów obcych w finansowaniu przedsiębiorstwa. Określenie udziału kapitałów obcych w finansowaniu aktywów umożliwia ocenę, czy występująca struktura kapitału nie jest podstawą do stwierdzenia zagrożenia dla niezależności finansowej podmiotu gospodarczego. Zasadniczym celem analizy zadłużenia jest także określenie kosztów oraz opłacalności korzystania z kapitałów obcych. Wyniki analizy powinny pomóc w stwierdzeniu, czy polityka finansowa przedsiębiorstwa jest odpowiednia i czy jest ono $\mathrm{w}$ stanie uregulować swoje zobowiązania w odpowiednim terminie w wymaganej wielkości (Gabrusewicz, 2005).

Znamienny jest fakt, że dobierając wskaźniki, należy uwzględnić co najmniej jeden obrazujący poziom zadłużenia podmiotu oraz jeden wskaźnik informujący o jego zdolności do obsługi długu.

Wskaźnik ogólnego zadłużenia (GDR) wyraża udział kapitałów obcych w finansowaniu aktywów firmy. Z punktu widzenia wierzycieli jest on niezwykle ważny, ponieważ w przypadku ogłoszenia upadłości przedsiębiorstwa odzyskują swoje należności z jego majątku (Wypych, 1998: 216). Wskaźnik ten oblicza się ze wzoru:

$$
\mathrm{D} / \mathrm{E}=\frac{\mathrm{TL}}{\mathrm{TA}}
$$

gdzie:

TL - zobowiązania ogółem,

TA - aktywa ogółem.

Wartość wskaźnika powinna mieścić się w przedziale $(0,5-0,7)$. Zbyt wysoka wartość wskaźnika, wyższa niż 0,7 , informuje o nadmiernym uzależnieniu finansowym przedsiębiorstwa. Niski zaś poziom świadczy o znaczącej samodzielności finansowej (Pieloch-Babiarz, Sajnóg, 2016).

Wskaźnik zadłużenia kapitału własnego uzupełnia ocenę zadłużenia firmy (Jerzemowska, 2004: 158) i wyrazić go można jako:

gdzie:

$$
\mathrm{D} / \mathrm{E}=\frac{\mathrm{TL}}{\mathrm{E}}
$$

E - kapitał własny,

pozostałe oznaczenia jw.

Określa on stopień zaangażowania kapitału obcego w stosunku do kapitału własnego. Za normę dla tego wskaźnika uznaje się poziom 0,5. Poziom wskaźnika zadłużenia kapitału własnego jest istotną miarą siły finansowej firmy. W praktyce dość często używa się odwrotności tego wskaźnika, co wynika z jego lepszej komunikatywności. Wskaźnik będący odwrotnością pozwala ustalić, ile kapitału własnego przypada na jedną jednostkę pieniężną zobowiązań długoterminowych (ING Securities, 2020, 15 września).

Wskaźnik zadłużenia długoterminowego jest jednym z ważniejszych wskaźników wypłacalności. Przyjmuje następującą formułę (Skoczylas, 2013: 262): 


$$
\mathrm{LDR}=\frac{\mathrm{LTL}}{\mathrm{E}}
$$

gdzie:

LTL - zobowiązania długoterminowe,

pozostałe oznaczenia jw.

Wskaźnik ten często nazywany jest również wskaźnikiem długu. Odnosi się on do zobowiązań długoterminowych, a więc tych, które są spłacane w okresach dłuższych niż roczne. Zadowalający poziom tego wskaźnika oscyluje w przedziale $(0,5-1,0)$. Górna racjonalna granica to 1,0, czyli sytuacja, w której zobowiązania długoterminowe są równe kapitałowi własnemu (ING Securities, 2020, 15 września).

Wskaźnik pokrycia obsługi długu (DSCR) przedstawia, jak wypracowany zysk pokrywa obsługę zobowiązań długoterminowych (Kurtys, 2002: 115 i nast.). Wyraża się go jako:

$$
\mathrm{DSCR}=\frac{\mathrm{GP}+\mathrm{I}}{\mathrm{PI}+\mathrm{I}}
$$

gdzie:

GP - zysk brutto,

PI - rata kapitałowa.

Ukazuje on poziom zabezpieczenia obsługi zobowiązań długoterminowych. Przyjmuje się, że jego wartość powinna przekraczać 1 oraz z upływem czasu wzrastać, co dowodzi efektywnego wykorzystywania zaciągniętych kredytów, pożyczek, które przyczyniają się do rozwoju przedsiębiorstwa oraz wzrostu wpływów z inwestycji (Pieloch-Babiarz, Sajnóg, 2016).

\section{Wskaźniki sprawności działania (obrotowości)}

Do określenia efektywności działania majątku stosuje się wskaźniki sprawności działania, inaczej nazywane wskaźnikami obrotowości majątkiem. Porównanie wybranych pozycji bilansowych z wartościami należącymi do rachunku zysków i strat zmusza do zastosowania średnich wartości składników majątku (Sierpińska, Jachna, 2007). Kluczowa jest ocena struktury wiekowej należności i zobowiązań przedterminowych. W przypadku gdy wskaźniki te znacznie odbiegają od przeciętnej z branży lub przekraczają 30 dni, należy wyjaśnić przyczyny takiego stanu. Porównuje się je z okresami tej samej wielkości.

Do najbardziej znanych wskaźników sprawności działania należą:

- wskaźnik rotacji aktywów całkowitych (TATA),

- wskaźnik rotacji majątku obrotowego,

- wskaźnik rotacji zapasów (IT),

- wskaźnik rotacji należności krótkoterminowych (RT) (Sierpińska, Jachna, 2007).

Wskaźnik rotacji aktywów całkowitych (TATA), przyjmuje postać (Czerny, 2006: 149): 


$$
\mathrm{TATA}=\frac{\mathrm{NS}}{\mathrm{ATA}}
$$

gdzie:

NS - przychody netto ze sprzedaży produktów, towarów i materiałów,

ATA - średni poziom aktywów całkowitych.

Wskaźnik rotacji majątku obrotowego z kolei informuje, ile razy w ciągu roku nastąpi odtworzenie aktywów obrotowych. Wylicza się go ze wzoru (Skoczylas, 2013: 242):

$$
\mathrm{CAT}=\frac{\mathrm{NS}}{\mathrm{ACA}}
$$

gdzie:

ACA - średni poziom aktywów obrotowych.

Zwiększenie wartości tego wskaźnika w danym odcinku czasowym dowodzi coraz lepszego wykorzystaniu aktywów obrotowych. W celu sprecyzowania analizy dokonuje się dekompozycji tego wskaźnika na wskaźnik rotacji zapasów oraz rotacji należności krótkoterminowych (Pieloch-Babiarz, Sajnóg, 2016).

Wskaźnik rotacji zapasów (IT) określa, ile razy w roku wystąpi odtworzenie zapasów. Opisuje się go, używając następującej formuły (Bednarski, 2007: 93; Dudycz, Wrzosek, 2000: 64-65):

$$
\mathrm{IT}=\frac{\mathrm{NS}}{\mathrm{AI}}
$$

gdzie:

AI - średni poziom zapasów.

Badanie tego wskaźnika pomaga przeciwdziałać zarówno niedoborom, jak i nadwyżce zapasów. Im niższa wartość wskaźnika, tym bardziej niekorzystna jest sytuacja w przedsiębiorstwie. Oznacza to, iż kapitał jest zamrożony w zapasach przez długi czas (Pieloch-Babiarz, Sajnóg, 2016).

Natomiast wskaźnik rotacji należności krótkoterminowych (RT) informuje, ile razy w ciągu roku przedsiębiorstwo odtworzyło stan należności. Ma on następującą postać (Bednarski, 2007: 94-95; Skoczylas, 2014: 242):

$$
\mathrm{RT}=\frac{\mathrm{NS}}{\mathrm{ASTR}}
$$

gdzie:

ASTR - średni poziom należności krótkoterminowych.

Wartość owego wskaźnika powinna wahać w przedziale 7-10. Wartość mniejsza od 7 oznacza, że przedsiębiorstwo kredytuje swoich odbiorców przez znaczny czas, co oznacza, iż jego środki pieniężne są zamrożone w należnościach (Pieloch-Babiarz, Sajnóg, 2016). 


\section{Wskaźniki rentowności}

„Podstawowym i najważniejszym zadaniem każdego przedsiębiorstwa prowadzącego działalność gospodarczą jest zapewnienie opłacalności tej działalności” (Gabrusewicz, 2014: 296-297). „Określenie «rentowność» pochodzi od terminu «renta», oznaczającego w najogólniejszym ujęciu zysk od kapitału. Rentowność przedsiębiorstwa wykazuje zasadniczą różnicę w stosunku do oprocentowania wypożyczonego kapitału obcego, gdyż jest to rezultat połączenia kapitału i pracy związanej z jego właściwym wykorzystaniem. Przez rentowność rozumie się na ogół zjawisko osiągnięcia przychodów przewyższających koszty działalności, czyli zjawisko wypracowania zysku. Rentowność (zyskowność) jest związana $z$ dodatnim wynikiem finansowym. Pojęciem przeciwstawnym do rentowności jest deficytowość, odnotowywana w przypadku występowania wyniku ujemnego czyli straty" (Jerzemowska, 2004: 281). Oceniając rentowność, w szczególności należy przeanalizować, w jakim stopniu wyniki okresów historycznych rzutują na wyniki jednostki gospodarczej w przyszłości.

Rozpatrując tę kwestię, warto zwrócić uwagę na takie wskaźniki rentowności, jak:

- Wskaźnik rentowności brutto (https://www.biznesplan.waw.pl/m/wskC.pdf):

$$
\mathrm{WZB}=\frac{\mathrm{ZB}}{\mathrm{SN}} * 100 \%
$$

gdzie:

ZB - zysk brutto,

$\mathrm{SN}$ - sprzedaż netto.

Wskaźnik ten określa wartości zysku brutto, tzn. przed opodatkowaniem, przypadającego na każdą złotówkę sprzedanych produktów i towarów.

- Wskaźnik rentowności aktywów (ROA) oblicza się ze wzoru (Bzunek, 2019):

$$
\text { ROA }=\frac{\text { Zysk netto }}{\text { Przeciętny stan aktywów }} * 100 \%
$$

Wskaźnik rentowności aktywów określa, ile złotych zysku generuje jedna złotówka majątku firmy. Najlepszą wartością dla ROA jest kilkadziesiąt procent. Jednak należy uważać, ponieważ bardzo wysoka rentowność jest zwykle trudna do utrzymania przez dłuższy czas, dlatego często bardziej cenione jest 10\% utrzymywane przez kilka lat niż jednorazowy skok na 30\%. Zatem zawsze warto zwrócić uwagę i przeanalizować wykres historycznego ROA i porównać go z ROA dla branży i szerokiego rynku (Fundamentalna Wyszukiwarka Giełdowa, 2020, 15 września).

- Wskaźnik rentowności kapitału własnego (ROE) jest relacją wyznaczaną według formuły (Analiza rentowności, 2020, 15 września):

$$
\mathrm{ROE}=\frac{\text { Zysk netto }}{\text { Przeciętny stan kapitału własnego }} * 100 \%
$$

Miernik rentowności kapitału własnego wskazuje, ile złotych zysku generuje jedna złotówka kapitału własnego. Rentowność kapitału własnego określa efektywność 
zaangażowanych środków własnych. Charakteryzuje ona w sposób syntetyczny jednostkę gospodarczą oraz umożliwia udzielenie odpowiedzi na pytanie o to, czy inwestycja w to przedsiębiorstwo opłaca się, a jeśli tak, to w jakim stopniu (Cebrowska, 2006).

- Wskaźnik rentowności sprzedaży (ROS) (Hamrol, 2010: 27-30):

$$
\text { ROS }=\frac{\text { Zysk netto }}{\text { Przychody ze sprzedaży }} * 100 \%
$$

Wskaźnik rentowności sprzedaży podaje, ile złotych zysku generuje jedna złotówka przychodów ze sprzedaży. Wskaźnik rentowności sprzedaży konfrontuje zysk netto, który został wypracowany z całej działalności przedsiębiorstwa w relacji do przychodów netto ze sprzedaży. Jego wielkość zależy od branży, w której działa przedsiębiorstwo. Bednarski stwierdza, że: „jest on stosunkowo najczęściej stosowany do prezentacji efektów finansowych uzyskanych ze sprzedaży produktów albo towarów i materiałów" (Bednarski, 2007). Wskaźnik rentowności sprzedaży jest najbardziej syntetycznym wskaźnikiem z grupy rentowności sprzedaży, z punktu widzenia kontynuowania działalności gospodarczej. Określa rentowność wypracowaną na podstawowej działalności operacyjnej, tzn. sprzedaży, do której de facto przedsiębiorstwo zostało utworzone i która jest kluczowa dla całej działalności (ING Securities, 2020, 15 września).

\section{Podsumowanie}

Kwintesencją analizy wskaźnikowej jest odpowiedni dobór wskaźników do prowadzonej działalności badanego podmiotu. W niniejszym artykule zostały przedstawione przykładowe mierniki znajdujące $\mathrm{z}$ łatwością zastosowanie aplikacyjne w praktyce. Tym samym należy podkreślić, że analiza wskaźnikowa nie ogniskuje się wokół pojedynczo wyliczonego miernika - wręcz przeciwnie - poszczególne obszary, w których obliczane są wskaźniki, niejako infiltrują ze sobą, przedstawiając holistyczne ujęcie aktualnego standingu finansowego przedsiębiorstwa. Badanie wskaźnikowe jest również istotne w zarządzaniu przedsiębiorstwem ze względu na to, że obszary płynności finansowej, rentowności, zadłużenia oraz sprawności działania są fundamentalnym ogniwem stanowiącym o modelowaniu relacji z szeroko pojmowanym otoczeniem zewnętrznym oraz realizacji wyznaczonego celu przedsiębiorstwa. Toteż analiza wskaźnikowa jest przydatnym narzędziem dla właścicieli, menedżerów oraz interesariuszy, którzy chcą poznać obecną kondycję finansową przedsiębiorstwa. Co więcej, w tym miejscu zasadne jest odwołać się do teorii interesariuszy przedsiębiorstwa, czyli stakeholders value, która wskazuje, iż działaniem przedsiębiorstwa zainteresowani są nie tylko właściciele, ale również zarząd, pracownicy, klienci, wierzyciele, kontrahenci, jednostki samorządowe i organizacje konsumenckie. Każda z wymienionych grup ma odmienne oczekiwania związane $\mathrm{z}$ aktywnością przedsiębiorstwa, a celem przedsiębiorstwa jest zrównoważenie oraz uwzględnienie $\mathrm{w}$ miarę równym stopniu interesów poszczególnych podmiotów (Michael, Hitt, Harrison, 2001). Przeciwstawne ujęcie prezentuje m.in. teoria shareholders value propagowana przez A. Rappaprta, M. Friedmana, czy P. Druckera. Zgodnie z nią przedsiębiorstwo powinno być zobligowane i ukierunkowane do takiego wyboru strategii oraz profilu zarządzania, aby maksymalizować wartość tworzoną wyłącznie dla jednej grupy, tzn. właścicieli. Cele innych interesariuszy są chronione przez wynegocjowane i zaakceptowane umowy (Resti, Sironi, 2007). Tym samym należy 
stwierdzić, iż decyzje przedsiębiorstwa określające misję oraz cele bezsprzecznie wpływają na kondycję finansową, a dalej na jego pozycję konkurencyjną. Niemniej jednak należy mieć również na uwadze, iż analiza ekonomiczno-finansowa ma pewne ograniczenia, wśród których z pewnością można wymienić relatywnie dużą ilość dostępnych do wykorzystania wskaźników. Komplikuje to oraz wydłuża proces przeprowadzanej oceny, a także zwiększa ryzyko popełnienia błędu. Dlatego w praktyce dla uzyskania jak najlepszych rezultatów winno się w sposób przemyślany oraz świadomy dokonywać wyboru najważniejszych mierników. Ponadto, uzyskane wyniki powinno się porównywać nie tylko z rekomendowanymi w literaturze przedmiotu wielkościami, lecz także z rezultatami osiąganymi przez przedsiębiorstwa działające w tej samej branży czy w tym samym sektorze. Zastosowanie takiego podejścia pozwoli na dokonanie jeszcze bardziej pogłębionych interpretacji prowadzących do wzbogacenia końcowych wniosków z przeprowadzonej analizy kondycji finansowej badanego podmiotu.

Literatura

References

Analiza rentowności. (2020, 15 września). Pozyskano z: https://analizy-prognozy.pl/analiza-prognoza-finansowa/analiza/wskaznikowa/rentownosci

Bednarski, L. (2007). Analiza finansowa w przedsiębiorstwie. Warszawa: PWE.

Bień, W. (2010). Czytanie bilansu przedsiębiorstwa (dla menedżerów). Warszawa: Difin.

Buk, H. (2007). Wpływ alternatywnego finansowego ujęcia aktywów finansowych na ocenę płynności finansowej. W: J. Duraj (red.), Problemy współczesnej analizy przedsiębiorstwa. Łódź: Wydawnictwo Uniwersytetu Łódzkiego.

Burzykowska, M., Duraj, J. (2009). Controllingowy wymiar oceny plynności finansowej przedsiębiorstwa. Łódź: Wydawnictwo Uniwersytetu Łódzkiego: 8 i nast.

Cebrowska, T. (2006). Rachunkowość finansowa i podatkowa. Warszawa: Wydawnictwo Naukowe PWN.

Bzunek, M. (2019). Wskaźnik rentowności aktywów (ROA) - wzór i przykład. Pozyskano z: https://econopedia.pl/fp/wskaznik-rentownosci-aktywow-roa-wzor-i-przyklad

Cicirko, T. (2010). Podstawy zarządzania plynnościa finansowa przedsiębiorstwa. Warszawa: Oficyna Wydawnicza Szkoła Główna Handlowa w Warszawie.

Czerny, J. (2006). Rachunkowość przedsiębiorstw w szczególnych sytuacjach. Poznań: Wyższa Szkoła Handlu i Rachunkowości w Poznaniu.

Dębski, W. (2013). Teoretyczne i praktyczne aspekty zarządzania finansami przedsiębiorstwa. Wydawnictwo Naukowe PWN.

Dudycz, T., Wrzosek, S. (2000). Analiza finansowa. Problemy metodyczne w ujęciu praktycznym. Warszawa: Wydawnictwo Akademii Ekonomicznej we Wrocławiu.

Fundamentalna Wyszukiwarka Giełdowa. (2020, 15 września). ROE. Pozyskano z: http://www.fundamentalna.net/wskazniki-rentownosci-przedsiebiorstwa

Gabrusewicz, W. (2005). Podstawy analizy finansowej. Warszawa: PWE.

Gabrusewicz, W. (2014). Analiza finansowa przedsiębiorstwa. Teoria i zastosowanie. Warszawa: PWE.

Grabowska, M. (2012). Zarządzanie plynnościa finansowa przedsiębiorstw. Warszawa: CeDeWu.

Hamrol, M. (2010). Analiza finansowa przedsiębiorstwa. Ujęcie sytuacyjne. Poznań: Wydawnictwo Uniwersytetu Ekonomicznego w Poznaniu.

https://www.biznesplan.waw.pl/m/wskC.pdf

ING Securities. (2020, 15 września). Analiza wskaźnikowa. Pozyskano z: https://www.edukacjagieldowa. $\mathrm{pl} /$ wp-content/uploads/2015/08/wskazniki.pdf

Jerzemowska, M. (2004). Analiza ekonomiczna w przedsiębiorstwie. Warszawa: PWE. 
Krajewski, M. (2006). Znaczenie kapitału pracującego w procesie kreowania wartości przedsiębiorstwa. W: E. Urbańczyk (red.), Strategie wzrostu wartości przedsiębiorstw. Szczecin: Wydawnictwo Naukowe Uniwersytetu Szczecińskiego: 116.

Kurtys, E. (2002). Analiza finansowa przedsiębiorstwa w przykładach i zadaniach. Poznań: Wydawnictwo Akademii Ekonomicznej w Poznaniu.

Michael, A., Hitt, J.S., Harrison, R. (2001). Mergers \& Acquisitions: A Guide to Creating Value for Stakeholders. New York: Oxford.

Michalski, G. (2010). Strategiczne zarządzanie plynnością finansową w przedsiębiorstwie. Warszawa: CeDeWu.

Pieloch-Babiarz, A., Sajnóg, A. (2016). Analiza fundamentalna. Standing finansowy i wycena przedsiębiorstwa. Łódź: Wydawnictwo Uniwersytetu Łódzkiego.

Prędkiewicz K. (2007). Wypłacalność małych i średnich przedsiębiorstw. W: J. Duraj (red.). Problemy wspótczesnej analizy ekonomicznej przedsiębiorstwa. Łódź: Wydawnictwo Uniwersytetu Łódzkiego.

Resti, A., Sironi, A. (2007). Risk Management and Shareholders' Value in Banking: From Risk Measurement Models to Capital Allocation Policies. West Sussex: Wiley Finance.

Siegel, J.G., Shim, J.K., Hartman, S.W. (1995). Przewodnik po finansach. Warszawa: Wydawnictwo Naukowe PWN.

Sierpińska, M., Jachna, T. (2007). Metody podejmowania decyzji finansowych. Warszawa: Wydawnictwo Naukowe PWN.

Sierpińska, M., Wędzki, D. (2010). Zarządzanie płynnościa finansową w przedsiębiorstwie. Warszawa: Wydawnictwo Naukowe PWN.

Skoczylas, W. (2013). Wskaźniki i systemy wskaźników ekonomicznych w pomiarze dokonań przedsiębiorstw. Szczecin: Wydawnictwo Naukowe Uniwersytetu Szczecińskiego.

Szyszko, L., Szczepański, J. (2003). Finanse przedsiębiorstwa. Warszawa: Polskie Wydawnictwo Ekonomiczne S.A.

Wiśniewski, T., Skoczylas, W. (1997). Analiza finansowa w przedsiębiorstwie. Poznań: Wyższa Szkoła Bankowa w Poznaniu.

Wrzosek, S. (2007). Kilka uwag w sprawie analizy płynności finansowej. W: J. Duraj (red.), Problemy wspótczesnej analizy ekonomicznej przedsiębiorstwa. Łódź: Wydawnictwo Uniwersytetu Łódzkiego: 178-179.

Wypych, M. (red.). (1998). Finanse przedsiębiorstwa z elementami zarządzania i analizy. Łódź: Wydawnictwo Absolwent.

Magdalena Lesiak, mgr, Uniwersytet Łódzki, Wydział Ekonomiczno-Socjologiczny, Katedra Rynku i Inwestycji Kapitałowych. Ukończyła studia magisterskie w ramach IPS, obecnie jest doktorantką na Wydziale Ekonomiczno-Socjologicznym Uniwersytetu Łódzkiego. Zdobyła III miejsce w XI edycji organizowanego przez Polskie Towarzystwo Ekonomiczne Oddział w Łodzi Konkursu na Najlepszą Pracę Magisterską z Zakresu Nauk Ekonomicznych. Zainteresowania badawcze autorki koncentrują się na analizie ekonomiczno-finansowej, finansach behawioralnych, etyce w finansach oraz rynku kapitałowym.

Magdalena Lesiak, MSc, University of Lodz, Faculty of Economics and Sociology, Department of Capital Market and Investments. She graduate of the Faculty of Economics and Sociology at the University of Lodz, graduated from MA studies at IPS, currently a PhD student in the Faculty of Economics and Sociology of the University of Lodz, Department of Capital Market and Investments. Winner of the third place in the 11th edition of the competition organised by the Polish Economic Society, Łódź Branch, for best MA Thesis in the field of Economic Sciences. The author's research interests focus on economic and financial analysis, behavioral finance, ethics in finance and the capital market.

ORCID: https://orcid.org/ 0000-0003-1320-4961

\section{Adres/Address:}


Uniwersytet Łódzki

Wydział Ekonomiczno-Socjologiczny

Katedra Rynku i Inwestycji Kapitałowych

ul. Polskiej Organizacji Wojskowej 3/5

90-255 Łódź, Poland

e-mail: magdalenalesiak2610@gmail.com 